\title{
Building Brand-Fan Relationships in Social Commerce Contexts: Mediators of Online Brand Relationships
}

\section{Li-Chun Hsu}

National Taitung University, Department of Cultural Resources and Leisure Industries, Taitung, Taiwan, R.O.C., Ichsu@nttu.edu.tw

Received 24 August 2017; received in revised form 18 June 2018; accepted 24 June 2018

\begin{abstract}
The effect of the Internet and social media on consumer behavior has recently begun to outweigh the effect of traditional marketing strategies. Therefore, numerous enterprises have begun to use social media to communicate with brand users, and social media has b"ecome the optimal tool for brand marketing. According to current brand-community relationships from the perspectives of brand authenticity and brand identification, we identified the mediating factors (brand trust and brand passion) of relationships between community members and brands and developed an integrated model to determine the effects of these factors on community member purchase intentions. The research targets in the present study were consumers who had purchased products from one of the top three cosmetic brands in Taiwan and had been a member of the brand's official fan page for at least 1 year. Overall, 484 valid samples were collected in this study. We employed structural equation modeling to examine our model. Five hypotheses were supported, and excellent model fits to the data were obtained. Additionally, this study discovered that brand trust and brand passion played crucial mediating roles. Finally, we propose management implications and make suggestions that can serve as a reference for brand community managers.
\end{abstract}

Keywords: Social commerce, Brand authenticity, Brand identification, Online brand relationships, Brand purchase intentions 


\section{Introduction}

Many enterprises have begun using social media to maintain the relationships between consumers and their brands [53]. Therefore, social networking sites are receiving attention from researchers, educators, practitioners, and decision-makers [21]. The mainstream use of social media, such as Facebook, Twitter, and consumer blogs, has become an effective tool for consumers to obtain independent information on brands and communicate their satisfaction or criticism of a brand to a broad audience [71].

Businesses often use social media to establish a relationship with social media users and deliver brand values. Brand authenticity is considered particularly crucial for forming a brand image [7]; establishing brand status, brand equity, and corporate reputation [35]; and marketing products [15]. In the past 10 years, brand authenticity has been considered a potential new pillar on which brand credibility and trust can be built [27], [70]. Gilmore and Pine [35] described the modern world as a corporate garden wherein all elements are included to have a particular effect and nothing remains authentic or unchanged. The current markets have been prettified or packaged by business operators, and consumers must learn to distinguish authentic products from adulterated products [22]. According to the book 2012 Trend Korea, brand authenticity is a critical indicator of the characteristics, appearance, and symbolism of a product when consumers are considering a purchase decision. Consumer perception of brand authenticity helps maintain a long-term relationship between a brand and its consumers [20]. Therefore, brand authenticity affects consumer purchase attitude toward the brand.

Brand authenticity is a novel concept that emerged during the past ten years and plays a crucial role in product purchase intention [22]. Various studies have explored brand authenticity. For example, Eggers et al. [27] revealed the relationships between brand authenticity, brand trust, and the growth of small and medium enterprises from the perspective of a chief executive officer. Bruhn et al. [15] developed a scale for measuring consumer perception of brand authenticity. Napoli et al. [62] measured the intensity of consumers' perceived brand authenticity. Coary [22] developed a scale on brand authenticity and investigated the effect of brand authenticity on brand trust and attitude. Finally, Choi et al. [20] reported multiple dimensions of brand authenticity and the relationship between brand authenticity, attachment, commitment, and loyalty. However, these studies have not investigated the relationships between consumers, brands, and Internet communities; the present study was conducted to explore these relationships.

Within the context of consumer relationship with a brand, a brand can be considered the basis of a brand community. Several factors must be considered if an excellent relationship with customers is to be developed. The concept of brand identification originated from social identity theory and can produce a series of consumer behavioral outcomes, including brand loyalty [40]. When consumers believe that their self-image resembles a brand's image, they use the brand to affirm their existence to themselves and society and to ensure that their attitude, values, and behavior are approved by society [29]. Researchers have reported that brand identification is conducive to brand management [51] and that strong brand identification enables customers to evaluate a brand favorably [25]. Accordingly, brand identification is a crucial dimension for consumers if they are to build a connection with a brand [70].

The second crucial factor for developing excellent relationships with customers is brand trust. The 2013 Edelman Trust Barometer reported that social media led to the most dramatic recent rise in brand trust worldwide [26]. The demand for truthful, honest, and trustworthy Brand-customer relationships is rising [71]. In a consumer-brand relationship context, trust is a necessary psychological requirement for developing customer loyalty.

The third factor affecting customer-brand relationships is how to encourage loyal fans to demonstrate their brand loyalty, which is crucial. The theory of Sternberg [73] explains why customers are strongly attracted to a brand. According to the triangular theory of love, also proposed by Sternberg [72], humans and commercial targets (e.g., products or brands) can develop a loving relationship similar to that between two individuals. Brand passion originates from brand love, which resembles love between individuals, except that one individual is a brand or product. Brand passion is considered stronger than brand love. Marketing researchers agree that passion is a core element for emotional connections and a crucial antecedent of customer loyalty [42].

Regarding exogenous variables, although some recent studies have explored brand loyalty, they have examined only from singular or individual perspectives, such as the effect of customer values and brand identification [80] on brand loyalty; similarly, study examined the influence of different community interactions (product-information, human-computer, and interpersonal interactions) on community identification [56]. Previous studies have investigated online brand relationships only from limited perspectives, such as the effect of brand passion [74] and brand trust [10] on brand purchase intentions. Therefore, the present study proposed that brand passion and brand trust be included to understand how consumers generate brand purchase intentions.

According to the triangular concept of brand community proposed by Muñiz, Jr. and O'Guinn [61], one association in the establishment of the Brand-community relationship is formed through links between brands and customers. How this differs from the Brand-customer relationship managed from the perspective of conventional offline marketing and whether the two essential factors of online brand relationships, brand trust and brand passion, play critical roles in 
Brand-customer relationships warrant investigation. These are crucial research topics that require further clarification. To date, no studies have comprehensively investigated the relationships of online brand relationship factors with their antecedents. Thus, we investigated the factors that affect the relationship between customers and brands and developed a comprehensive brand relationship model to understand how existing brands have established excellent brand relationships with their fans and stimulated purchase intentions. The purposes of this study were as follows: (a) to investigate brand authenticity and its individual relationship with brand trust and passion, (b) to investigate brand identification and its individual relationship with brand trust and passion, (c) to explore the individual effect of brand trust and passion on brand purchase intentions, (d) to investigate the mediation roles of brand trust and passion, and (e) to compare different effects of gender on brand passion.

\section{Literature Review and Research Hypotheses}

The literature section proposes research framework, the relevant theory and the different constructs adpoted in the study, and hypothesizing relationships among these variables.

\subsection{Research Framework}

In this study, brand authenticity and brand identification (as defined in social identity theory; SIT) served as the foundation for the development of a theoretical model. The main content of identity perspective is derived from selfcategorization theory [77] and SIT [75]. SIT is considered useful for understanding customer behavior because customers are not required to act openly with other customers (or even understand them) but consider themselves part of a social group [52]. Applying SIT to brand community topics can explain the key points of community members' community identification formation. In virtual community contexts, community member brand identity helps members identify with the brand community to which they belong [81]. In particular, when they believe that their selfimage closely resembles the appeal of the brand in question, consumers verify the appropriateness and necessity of their self-existence through brands to consider whether their attitudes, values, and behaviors are socially acceptable [29].

In addition, the mediation roles of brand trust and passion in brand relationships were explored to understand the brand purchase intentions of fans. Figure 1 illustrates the research framework.

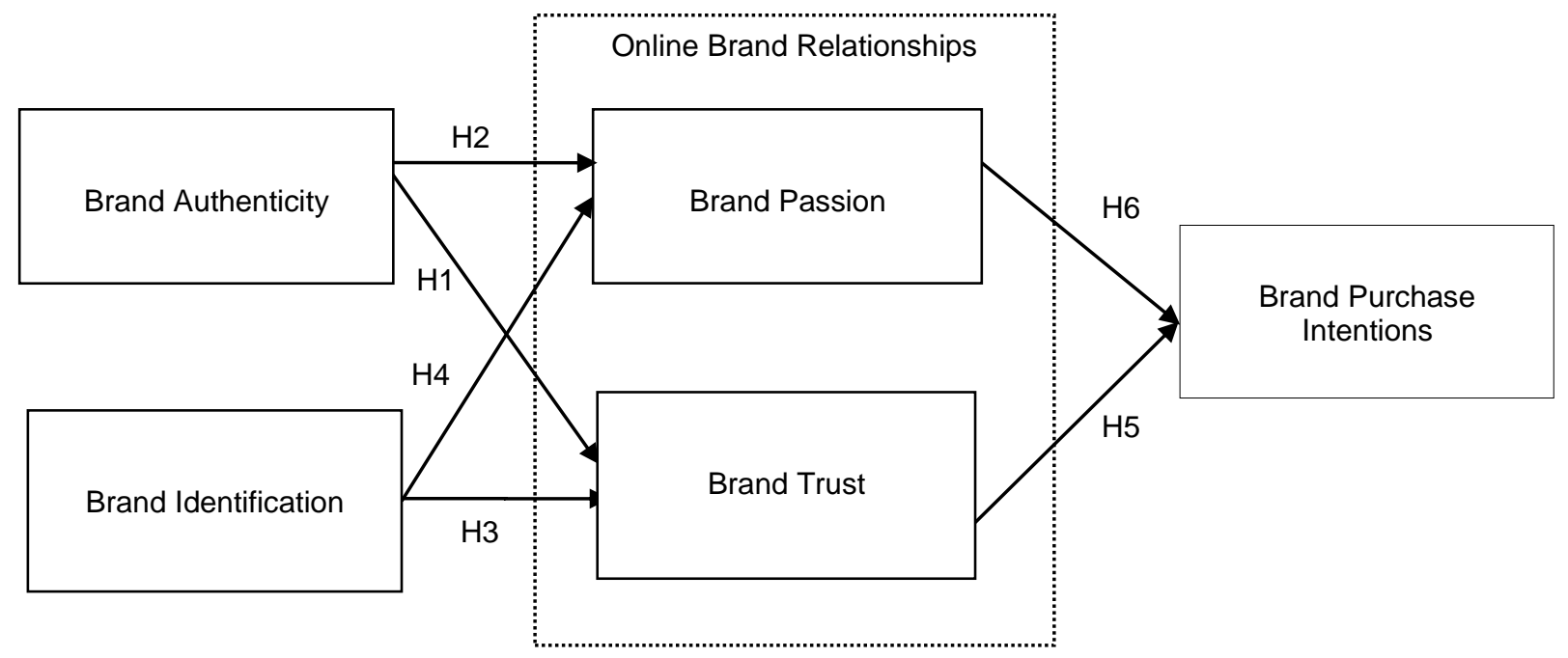

Figure 1: Proposed model

\subsection{Brand Authenticity}

The word authenticity, which originated from the Latin word authenticus and the Greek word authentikos, is defined as the quality of being authoritative, valid, true, real, genuine, or trustworthy [16]. In the humanities and social sciences, the concept of authenticity has broad connotations and researchers have provided various explanations for it [15]. As Kim et al. [50] reported, if a corporate brand clearly expresses the characteristics of a product or provides an authentic experience to consumers, the consumers are aware of the brand's authenticity [20].

Studies have defined the concept and dimensions of brand authenticity differently. Bruhn et al. [15] investigated consumer understanding of brand authenticity and reported that brand authenticity has four dimensions: continuity, originality, reliability, and naturalness. Eggers et al. [27] proposed three operational factors of brand authenticity: brand consistency, customer orientation, and brand congruency. Coary [22] concluded that brand authenticity has three components: being a category pioneer, maintaining the original product formulation, and adhering to certain 
brand principles. Napoli et al. [62] conducted a consumer-oriented study and developed a consumer-based brand authenticity scale comprising three dimensions: quality commitment, sincerity, and heritage. Choi et al. [20] revealed that brand authenticity has seven dimensions: authority, fashionability, consistency, innovativeness, sustainability, originality, and heritage. Based on the aforementioned studies, brand authenticity can be defined as a customer's consideration of the degree to which a brand is genuine, natural, honest, consistent, and unique.

\subsection{Social Identity Theory and Brand Identification}

Social identity involves clarifying self, group, and intergroup concepts and relationships [39]. Consumer brand identification can be understood through social identity theory and social psychology [78]. Personal brand identification originates in a consumer's affinity with a brand. When a consumer is a brand community member, their social brand identification is reinforced [54]. A rich brand image that matches and protects a customer's self-image leads to a favorable evaluation of the brand, which in turn enhances the brand's reputation [43]. Strong brand identification indicates that brand users believe themselves to belong to a specific brand [52]. According to some studies, brand identification means that brand users consider a brand as a reference point to distinguish the brand's users from its nonusers [30]. Kim et al. [48] concluded that a brand can reinforce consumer brand identification to some degree.

Brands have become crucial for establishing a relationship with consumers and ensuring successful business operation [77]. Consumer brand identification is crucial for brand management, increasingly receives attention from experts and researchers [12], and affects the relationship between consumer behavior and brands; therefore, consumer brand identification should be further understood. According to Escalas and Bettman [30], Kuenzel and Halliday [52], and Yeh and Choi [81], brand identification can be defined as consumers identifying with a certain brand and considering themselves part of a specific group.

\subsection{Brand Trust and Passion within Online Brand Relationships}

To address the relevant constrcuts definitions in online brand relationships, including brand trus and brand passion.

\subsubsection{Brand Trust}

The concept of trust has been explored in various fields (e.g., social psychology, sociology, and commerce and marketing). Brand trust is composed of cognitive beliefs [24] and emotional perceptions [28]. Cognitive beliefs include predictable expectations concerning the reliability, consistency, competitiveness, and performance of a product [24]. Emotional perceptions, however, include evaluations stemming from emotions, from which emotionrelated expectations, such as a brand's trustworthiness and benevolence, arise [11]. Therefore, consumers believe that the brand can meet their requirements, and consumer interests are the priority when consumer disputes occur [24].

Brand trust indicates that consumers believe the brand has authentic product features [36]. Therefore, trust is consumer confidence that a brand business operator is fulfilling commitments and selling their product at a reasonable price. Brand trust has two dimensions: brand credibility (i.e., a brand has the ability to keep its promises and meet customer requirements) and consumer protection (i.e., a brand has the ability to protect consumer interests) [69]. Accordingly, a trustworthy brand always keeps its promises to consumers during development, production, sales activity, service provision, marketing activity, and product crises. Therefore, a trustworthy brand image helps the brand maintain a long-term cooperative relationship with customers. Based on this description, the present study combined the views of Bruhn et al. [14] and Habibi et al. [37] and defined brand trust as consumer confidence in the credibility of a brand and in the owners of said brand to fulfill their commitments.

\subsubsection{Brand Passion}

Brand passion is a core element of the consumer-brand relationship [74]. According to the triangular theory of love proposed by Sternberg [73], love is composed of three components, one of which is passion [74]. This theory has been applied in studies investigating consumption behavior. According to Bauer et al. [9], brand passion is a strong positive feeling toward a specific brand that leads to emotional attachment and affects related behavior and also explains consumer passion within consumer-brand relationships. In summary, passion is a strong desire and feeling, and when a person is passionate about someone or something, they exhibit certain behaviors. This study combined the views of Bauer et al. [9] and Albert and Valette-Florence [2] to define brand passion as a strong positive attitude and infatuation toward a particular brand.

\subsection{Relationships among brand authenticity, brand identification, brand trust, and brand passion}

People's trust in other parties is primarily dependent on whether other parties can be understood, what other parties have accomplished, and whether these parties have favorable reputations [4]. Similarly, these characteristics are the elements used by consumers to establish trust in a brand. The antecedents of authenticity (e.g., the consistency of 
brand marketing strategies and the originality of brand products) can enhance brand credibility and reputation [22]. Brand trust has the following cognitive dimensions: brand credibility, consistency, success, and predictability [11], [24]. When consumers perceive a high level of brand authenticity, they present a high level of brand trust [62]. Brand trust was defined as consumer belief that a brand will keep its promises [18]. The brand commitment of a product with brand authenticity reflects the brand's characteristics and its willingness to fulfill its promises. One study reported that the two aspects of brand authenticity (i.e., brand consistency and continuity) significantly and positively affect brand trust [27]. Brand authenticity was also demonstrated to enhance brand trust [71]. Thus, brand authenticity substantially affects brand trust. Therefore, we proposed the following hypothesis $(\mathrm{H} 1)$ :

\section{H1: Brand authenticity positively affects brand trust.}

Consumers who perceive high authenticity positively perceive their own characteristics strongly; accordingly, consumers' perception of brand authenticity reflects their personal intentions to be authentic [22]. Swimberghe et al. [74] revealed that being able to reinforce self-concepts or reflect a personal brand positively affects brand passion. Brand authenticity affects the brand identification of consumers who have a close relationship with the brand [22]. Brand authenticity is thus a crucial factor affecting successful brand identification [15]. In addition, brand passion can express consumer values and demonstrate brand identification. Therefore, brand identification is positively related to brand passion [3]. In summary, brand authenticity substantially affects brand passion. Thus, we proposed the following hypothesis $(\mathrm{H} 2)$ :

\section{H2: Brand authenticity positively affects brand passion.}

\subsection{Relationships between Brand Identification and Brand Trust}

Brand identification is based on consistency between consumers and brands, it also reflects a brand's symbolism in society, and is shared among people in a community [30]. It can reflect consumers' personalities, improve their selfesteem and social status, and help them form a long-term relationship with a brand [79]. Mutual trust is crucial for successful social interactions. Therefore, building a trusting relationship with customers, employees, investors, and other organizations is crucial for companies. Customers often identify with trustworthy organizations as a way to express their self-definitions and enhance their self-esteem [57]. When organizations that have the trust of consumers are competent, benevolent, and honest, the consumers become aware of the relationship between their self-identification and the organization's specific brands. Therefore, we proposed in this study the following hypothesis $(\mathrm{H} 3)$ :

\section{H3: Brand identification positively affects brand trust.}

Napoli, Dickinson, Beverland, and Farrelly [62] revealed that postmodern consumers use brands to create a true self and reconnect themselves to particular locations, time points, and cultures. When a consumer strongly identifies with a brand, the consumer and other consumers who love the same brand form a brand community [59]; these consumers' self-identification and social identification become brand identification [47]. Brand passion reflects consumer personality in addition to internal emotions. Recent studies have demonstrated that when consumers love a brand, their brand identification is central to their brand passion. Studies have indicated that brand identification enhances brand passion [3]. Thus, we proposed the following hypothesis ( $\mathrm{H} 4)$ :

\section{H4: Brand identification positively affects brand passion.}

\subsection{The Effect of Brand Trust and Brand Passion on Brand Purchase Intentions}

Brand trust can affect consumer attitude and behavior (including purchase behavior, attitudinal and behavioral loyalty, perceptions of brand value, and brand referrals) toward a brand [24], [28]. Becerra and Korgaonkar [11] investigated trust as it relates to the quality of the Internet environment and discovered that brand trust can enhance willingness to purchase online. Similarly, Reichheld [67] concluded that a person's recommendation of a brand to others may affect their own reputation; therefore, consumers tend to recommend only trustworthy brands that meet their expectations. Therefore, authenticity not only inspires trust in consumers but also makes them willing to pay a premium price [13]. Thus, we proposed the following hypothesis (H5):

\section{H5: Brand trust positively affects brand purchase intentions.}

Marketing researchers have achieved consensus that passion is the core element of emotional connection and leads to consumer loyalty [9]. Rozanski et al. [68] reported that brand fanatics are passionate and loyal to their favorite brands and therefore develop extreme behavior. Accordingly, consumers can be brand messengers who communicate their brand love by word of mouth and encourage others to purchase and use the brand [17]. Turri et al. [76] concluded that passionate consumers are highly likely to develop repetitive purchase behavior. Based on these arguments, we proposed the following hypothesis $(\mathrm{H} 6)$ :

H6: Brand passion positively affects brand purchase intentions. 


\section{Methodology}

The section addresses source of sample, data collection, measures, operational definitions and scales adpoted in the study.

\subsection{Sample and Data Collection}

We selected the fan clubs of the top three cosmetic brands in Taiwan as the study population, chosen according to the Cosmetic Marketing Research Institution's [23] 2015 Q4 report on the number of views each brand's cosmetic products received on UrCosme.com. The three brands (Lancôme, Kiehl's, and Shiseido) are renowned international cosmetic brands. We sampled participants from the Facebook fan clubs of Lancôme, Kiehl's, and Shiseido. The participants must have purchased a product from one of the three brands and been members of the fan page for at least a year. Most respondents were notified of the survey through postings of online questionnaires on the brands' Facebook fan pages and the forums of beauty and cosmetics website Fashion Guide. Fan page and forum members were encouraged to forward the questionnaire to other members. They were invited to use the online MySurvey platform to complete a questionnaire. The first question was used to determine whether a participant qualified to participate in the survey.

The formal questionnaire survey was conducted from March 1 to June 30, 2016 (approximately 4 months). In total, 568 questionnaires were returned; after removing 84 invalid questionnaires, 484 valid questionnaires remained for data analysis. The valid return rate was $85.21 \%$. The valid questionnaires were completed by 103 male $(21.30 \%)$ and 381 female $(78.70 \%)$ participants. Most users of beauty and cosmetic products are women, indicating great potential for product development to cater to men. Men often consult female friends before making purchases, and most men's beauty and cosmetic products are purchased by women.

Table 1: Demographics of respondents

\begin{tabular}{|c|c|c|}
\hline Variable & Frequency & Percentage \\
\hline \multicolumn{3}{|l|}{ Gender } \\
\hline Male & 103 & 21.30 \\
\hline Female & 381 & 78.70 \\
\hline \multicolumn{3}{|l|}{ Age } \\
\hline $15-24$ & 154 & 31.80 \\
\hline $25-34$ & 143 & 29.50 \\
\hline $35-44$ & 105 & 21.70 \\
\hline $45-54$ & 68 & 14.00 \\
\hline$>55$ & 14 & 2.90 \\
\hline \multicolumn{3}{|l|}{ Education } \\
\hline$<$ High school & 72 & 14.90 \\
\hline College & 337 & 69.60 \\
\hline$>$ Graduate & 75 & 15.50 \\
\hline \multicolumn{3}{|l|}{ Living area } \\
\hline Northern & 246 & 50.80 \\
\hline Central & 114 & 23.60 \\
\hline Southern & 99 & 20.50 \\
\hline East & 25 & 5.10 \\
\hline \multicolumn{3}{|c|}{ Average spent online of daily time } \\
\hline$<1$ hour & 171 & 35.30 \\
\hline $2-4$ hours & 190 & 39.30 \\
\hline $5-7$ hours & 77 & 15.90 \\
\hline$>8$ hours & 46 & 9.50 \\
\hline \multicolumn{3}{|c|}{$\begin{array}{l}\text { Average spent Facebook fan page of } \\
\text { daily time }\end{array}$} \\
\hline$<1$ hours & 240 & 49.60 \\
\hline$>1$ hours & 244 & 50.40 \\
\hline \multicolumn{3}{|c|}{ Contact Facebook time } \\
\hline$<1$ year & 9 & 1.90 \\
\hline $1-2$ years & 23 & 4.80 \\
\hline $2-3$ years & 27 & 5.60 \\
\hline 3-4 years & 18 & 3.70 \\
\hline$>4$ years & 407 & 84.10 \\
\hline
\end{tabular}


Regarding their ages, 31.80\%, 29.50\%, 21.70\%, 14.00\%, and 2.90\% of the participants were 15-24, 25-34, 35-44, 45-54, and over 55 years of age, respectively. That is, most participants were young adults. Participants most commonly had earned bachelor's degree $(69.60 \%)$, lived in northern Taiwan $(50.80 \%)$, and surfed the Facebook fan page of one of the three cosmetic brands for more than $1 \mathrm{~h}$ each day $(50.40 \%)$. By daily Internet use, the largest proportion of participants $(39.30 \%)$ used the Internet for $2-4 \mathrm{~h}$ on average. Nearly as many participants used the Internet for less than $1 \mathrm{~h}(35.30 \%)$, and the next largest group used the Internet for $5-7 \mathrm{~h}(15.90 \%)$ each day. Most participants used the Internet for at least some time every day and had been using Facebook for more than 4 years $(84.10 \%)$.

\subsection{Measures and Operational Definitions}

In this study, various scales were designed based on scales proposed in other studies. A seven-point Likert scale was adopted for the brand authenticity and brand identification scales $(1=$ strongly disagree and $7=$ strongly agree $)$. A five-point Likert scale was used in the brand trust, brand passion, and brand purchase intention scales ( $1=$ strongly disagree and 5 = strongly agree; refer to Appendix 1 for the items in each scale). The adoption of preventive measures can effectively eliminate common method variance (CMV), which is particularly severe when respondents repeatedly encounter the same types of questions and scales. Therefore, to maintain the stability of the original author's scale design and to prevent single-source bias, this study followed the original questionnaire scale designed by its authors to prevent the respondents from producing errors of consistent responses when encountering items from a single scale. When the questionnaires were analyzed, the scale scores were first standardized before causality verification was conducted.

\subsubsection{Brand Authenticity}

In this study, following the measured dimensions proposed by Bruhn et al. [15], brand authenticity was operationally defined as the fans of a brand considering its continuity, originality, reliability, and naturalness. For the brand authenticity scale, we used 15 items originally proposed by Bruhn et al. [15].

\subsubsection{Brand Identification}

Similarly, following the definitions proposed by Escalas and Bettman [30] and Yeh and Choi [81], brand identification was operationally defined as the degree to which brand community members use the brand in question as a reference point to compare themselves with nonusers of the brand and consider the brand's image part of their selfimage. In the brand identification scale, we used three items originally used by Yeh and Choi [81].

\subsubsection{Online Brand Relationship Factors: Brand Trust and Brand Passion}

We divided brand relationship factors into three categories: brand trust and brand passion. Our notions of brand trust mainly followed from the views of Bruhn et al. [14] and Habibi et al. [37], who operationally defined brand trust as brand fans considering a brand trustworthy and reliable. Brand passion mainly followed the views of Hwang and Kandampully [45] and Mohammadian et al. [60], who operationally defined brand passion as brand fans being passionate about a brand. In total, six items were used to assess brand trust (three items originally used by Habibi et al. [37]) and brand passion (three items originally used by Kim et al. [49]).

\subsubsection{Brand Purchase Intention}

Brand purchase intention was defined primarily by following the definition proposed by Becerra and Badrinarayanan [10]; the definition was revised to be the likelihood of a brand community member purchasing a brand's product. For the scale, four items originally used by Becerra and Badrinarayanan [10] were used.

\section{Results}

Structural equation modeling and the statistical software package AMOS 18.0 were used to analyze data. Following Anderson and Gerbing [5], structural equation modeling was used to analyze data in two stages. In the first stage (measurement model analysis), we determined whether the latent variables could be correctly measured from the measured variables. To assess discriminant validity, we conducted three tests. First, the average variance extracted (AVE) criterion proposed by Fornell-Larcker [32] was employed to test whether the square root of the AVE for each construct was higher than all correlations of the considered construct. Second, the present study adopted the heterotrait-monotrait (HTMT) technique to ensure the level of adequacy of each construct varied between $\mathrm{HTMT}_{0.90}$ and HTMTinference. Third, we used the cross-loading method [19] to test whether each construct could be effectively distinguished. In the second stage (structural model analysis), we used structural pattern analysis to determine the causal relationships between various variables. Finally, the mediation effects of brand trust and brand passion were examined through a Sobel test, bootstrapping, and regression analysis. 


\subsection{Measurement Model}

We adopted in this study the assessment criteria for convergent validity suggested by Anderson and Gerbing [5], the assessment standards for confirmatory factor analysis proposed by Bagozzi and Yi [6], and the fitness index developed by Gefen et al. [34]. The measurement model developed in the present study had an excellent fit to the data $\left(X^{2} / \mathrm{df}=2.919\right.$, goodness-of-fit index $(\mathrm{GFI})=0.853$, adjusted goodness-of-fit index $(\mathrm{AGFI})=0.823$, comparative fit index $(\mathrm{CFI})=0.955$, and root mean square error of approximation $(\mathrm{RMSEA})=0.063)$. According to Hu and Bentler [44], a GFI or AGFI of 0.8 or higher is acceptable. In the present study, composite reliability and AVE were assessed according to the suggestion of Gaski and Nevin [33] that they should be greater than 0.7 and 0.5 , respectively. Therefore, the convergent validity of each subscale used in the present study was acceptable. Table 2 presents the results of the measurement model analysis.

Table 2: Measurement model

\begin{tabular}{|l|l|l|l|l|l|}
\hline Scale/ltems & Factor loading & SMC & CR & AVE & Cronbach's a \\
\hline Brand authenticity & & & 0.956 & 0.615 & 0.960 \\
\hline BA1 & 0.744 & 0.553 & & & \\
\hline BA2 & 0.743 & 0.552 & & & \\
\hline BA3 & 0.752 & 0.565 & & & \\
\hline BA4 & 0.779 & 0.607 & & & \\
\hline BA5 & 0.801 & 0.642 & & & \\
\hline BA6 & 0.804 & 0.647 & & & \\
\hline BA7 & 0.811 & 0.658 & & & \\
\hline BA8 & 0.793 & 0.628 & & & \\
\hline BA9 & 0.798 & 0.637 & & & \\
\hline BA10 & 0.845 & 0.714 & & & \\
\hline BA11 & 0.837 & 0.705 & & & \\
\hline BA12 & 0.792 & 0.628 & & & \\
\hline BA13 & 0.679 & 0.461 & & & \\
\hline BA14 & 0.830 & 0.689 & & & \\
\hline BA15 & 0.741 & 0.549 & & & \\
\hline Brand identification & & & 0.865 & 0.681 & 0.894 \\
\hline BI1 & 0.844 & 0.712 & & & \\
\hline BI2 & 0.840 & 0.706 & & & \\
\hline BI3 & 0.790 & 0.624 & & & \\
\hline Brand trust & & & 0.848 & 0.650 & 0.847 \\
\hline BT1 & 0.790 & 0.624 & & & \\
\hline BT2 & 0.819 & 0.672 & & & \\
\hline BT3 & 0.810 & 0.656 & & & \\
\hline Brand passion & & & 0.900 & 0.750 & 0.904 \\
\hline BP1 & 0.814 & 0.663 & & & \\
\hline BP2 & 0.896 & 0.839 & & & \\
\hline BP3 & 0.885 & 0.784 & & & \\
\hline Brand purchase intentions & & & 0.884 & 0.655 & 0.883 \\
\hline BPI1 & 0.810 & 0.656 & & & \\
\hline BPI2 & 0.823 & 0.677 & & & \\
\hline BPI3 & 0.811 & 0.658 & & & \\
\hline BPI4 & 0.793 & 0.629 & & & \\
\hline
\end{tabular}

Podsakoff et al. [65] advised to use multiple methods and control for CMV. This study used the following three methods to test as follows. Following Fornell and Larcker [32], we first used AVE to assess discriminant validity. If the square root of the AVE of a latent variable was greater than the correlation coefficient between the two underlying dimensions, then the two underlying dimensions possessed excellent discriminant validity. The results verified that correlation coefficients between every pair of constructs were less than the square root of the AVE for each construct (Table 3).

Henseler et al. [41] stated that in variance-based structural equation modeling the HTMT technique provides superior assessments of discriminant validity to those of AVE. Therefore, we adopted the HTMT technique to assess discriminant validity to ensure the adequacy of the model constructs. If the HTMT confidence interval value is less than 0.9 , it means that the model has discriminant validity. Table 4 shows that the HTMT value of each construct was less than 0.9 ; therefore, no discriminant validity problem existed in this study. 
Table 3: Correlation matrix

\begin{tabular}{|c|c|c|c|c|c|c|c|}
\hline Variable & Mean & SD & 1 & 2 & 3 & 4 & 5 \\
\hline 1 Brand authenticity & 5.258 & 0.755 & 0.784 & & & & \\
\hline 2 Brand identification & 5.234 & 0.788 & $0.725^{\star \star \star}$ & 0.828 & & & \\
\hline 3 Brand trust & 4.068 & 0.566 & $0.763^{\star \star \star}$ & $0.716^{\star \star \star}$ & 0.806 & & \\
\hline 4 Brand passion & 4.967 & 0.910 & $0.670^{* * *}$ & $0.612^{* * *}$ & $0.597^{* * *}$ & 0.866 & \\
\hline 5 Brand purchase intentions & 3.794 & 0.569 & $0.622^{* \star *}$ & $0.590^{* * *}$ & $0.566^{* * *}$ & $0.554^{\star \star *}$ & 0.809 \\
\hline
\end{tabular}

Note: ${ }^{* * *} p<0.001$; Diagonal elements are the square root of the average variance extracted for all constructs.

Table 4: HTMT analysis

\begin{tabular}{|c|c|c|c|c|c|}
\hline Variable & $\begin{array}{l}\text { Brand } \\
\text { Authenticity }\end{array}$ & $\begin{array}{l}\text { Brand } \\
\text { Identification }\end{array}$ & Brand Trust & Brand Passion & $\begin{array}{l}\text { Brand Purchase } \\
\text { Intentions }\end{array}$ \\
\hline \multicolumn{6}{|l|}{$\begin{array}{l}\text { Brand } \\
\text { Authenticity }\end{array}$} \\
\hline $\begin{array}{l}\text { Brand } \\
\text { Identification }\end{array}$ & $\begin{array}{l}0.896 \\
\text { Cl.90 [0.90;0.93] }\end{array}$ & & & & \\
\hline Brand Trust & $\begin{array}{l}0.759 \\
\text { Cl.90 }[0.55 ; 0.86]\end{array}$ & $\begin{array}{l}0.707 \\
\text { Cl.90 [0.75;0.86] }\end{array}$ & & & \\
\hline Brand Passion & $\begin{array}{l}0.720 \\
\text { Cl.90 [0.58;0.93] }\end{array}$ & $\begin{array}{l}0.669 \\
\text { Cl.90 [0.60;0.72] }\end{array}$ & $\begin{array}{l}0.679 \\
\text { Cl.90 [0.63;0.74] }\end{array}$ & & \\
\hline $\begin{array}{l}\text { Brand } \\
\text { Purchase } \\
\text { Intentions }\end{array}$ & $\begin{array}{l}0.847 \\
\text { Cl.90 [0.61;0.72] }\end{array}$ & $\begin{array}{l}0.819 \\
\text { Cl.90 [0.59;0.71] }\end{array}$ & $\begin{array}{l}0.761 \\
\text { Cl.90 [0.59;0.72] }\end{array}$ & $\begin{array}{l}0.685 \\
\text { Cl.90 [0.53;0.69] }\end{array}$ & \\
\hline
\end{tabular}

The cross-loadings of each construct shown in Table 5 were determined by calculating the loadings of each item on its own construct and the cross-loadings on other constructs. The factor loading of each item on its own construct was higher than the cross-loadings on other constructs; thus, no significant overlap was observed between any constructs in the overall model. Each construct was effectively distinguished. Tables 3-5 indicate good discriminate analysis based on the criteria of Fornell and Larcker [32], Hair et al. [38], and Henseler et al. [41].

Table 5: Cross-loading of constructs

\begin{tabular}{|c|c|c|c|c|c|}
\hline \multirow{2}{*}{ Ítems } & \multicolumn{5}{|l|}{ Factor } \\
\hline & 1 & 2 & 3 & 4 & 5 \\
\hline BA1 & 0.665 & -0.005 & 0.014 & 0.196 & 0.191 \\
\hline BA2 & 0.671 & 0.018 & 0.137 & 0.076 & 0.011 \\
\hline BA3 & 0.712 & -0.015 & -0.150 & 0.238 & 0.068 \\
\hline BA4 & 0.660 & 0.104 & 0.007 & 0.043 & 0.038 \\
\hline BA5 & 0.650 & 0.220 & 0.039 & -0.085 & -0.003 \\
\hline BA6 & 0.643 & 0.164 & 0.164 & -0.158 & -0.043 \\
\hline BA7 & 0.723 & 0.079 & 0.125 & -0.027 & -0.002 \\
\hline BA8 & 0.764 & 0.002 & 0.004 & 0.012 & 0.023 \\
\hline BA9 & 0.552 & 0.338 & 0.163 & -0.125 & 0.057 \\
\hline BA10 & 0.755 & 0.070 & 0.083 & 0.018 & -0.050 \\
\hline $\mathrm{BA} 11$ & 0.856 & 0.088 & -0.095 & -0.045 & 0.068 \\
\hline BA12 & 0.882 & 0.037 & -0.031 & -0.003 & 0.092 \\
\hline BA13 & 0.668 & -0.094 & 0.109 & 0.089 & -0.003 \\
\hline BA14 & 0.677 & 0.100 & 0.041 & 0.173 & -0.042 \\
\hline BA15 & 0.571 & 0.018 & 0.131 & 0.060 & -0.041 \\
\hline $\mathrm{Bl} 1$ & 0.043 & 0.767 & 0.098 & 0.030 & -0.047 \\
\hline $\mathrm{BI} 2$ & 0.058 & 0.872 & -0.079 & -0.027 & 0.075 \\
\hline
\end{tabular}




\begin{tabular}{|l|l|l|l|l|l|}
\hline \multicolumn{6}{|l|}{ Table 5: continuation } \\
\hline BI3 & 0.029 & $\mathbf{0 . 8 7 8}$ & -0.026 & 0.005 & 0.105 \\
\hline BP1 & 0.012 & 0.007 & $\mathbf{0 . 8 7 8}$ & -0.023 & 0.052 \\
\hline BP2 & 0.123 & 0.020 & $\mathbf{0 . 7 2 3}$ & 0.131 & 0.091 \\
\hline BP3 & 0.026 & 0.058 & $\mathbf{0 . 7 5 3}$ & 0.082 & 0.085 \\
\hline BT1 & 0.096 & 0.177 & 0.203 & $\mathbf{0 . 5 5 7}$ & 0.021 \\
\hline BT2 & 0.161 & 0.096 & 0.065 & $\mathbf{0 . 6 3 6}$ & 0.056 \\
\hline BT3 & 0.145 & 0.174 & 0.104 & $\mathbf{0 . 5 4 6}$ & 0.023 \\
\hline BPI1 & 0.093 & -0.031 & 0.045 & -0.087 & $\mathbf{0 . 8 1 1}$ \\
\hline BPI2 & 0.019 & -0.032 & 0.199 & -0.026 & $\mathbf{0 . 7 8 8}$ \\
\hline BPI3 & 0.122 & 0.020 & -0.058 & 0.049 & $\mathbf{0 . 7 0 0}$ \\
\hline BPI4 & -0.118 & 0.149 & -0.030 & 0.064 & $\mathbf{0 . 8 4 8}$ \\
\hline
\end{tabular}

\subsection{Structural Model}

The model fit indices (values) used in this study were as follows: $X^{2} / \mathrm{df}$ (2.928), GFI (0.852), AGFI (0.824), nonnormed fit index (NFI, 0.933), CFI (0.955), incremental fit index (IFI, 0.955), and RMSEA (0.063). According to $\mathrm{Hu}$ and Bentler [44], a GFI or AGFI of 0.8 or higher is acceptable. Therefore, the structural model in the present study was well fitted to the data.

The value $\gamma$ denotes the path relationship between an exogenous variable and an endogenous variable, whereas $\beta$ denotes the path relationship between two endogenous variables. Regarding the hypothetical model, brand authenticity was discovered to significantly and positively affect brand trust $\left(\gamma_{11}=0.853, p<0.001\right)$ but did not significantly affect brand passion $\left(\gamma_{21}=0.104, p>0.05\right)$, whereas brand identification significantly and positively affected both brand trust $\left(\gamma_{12}=0.245, p<0.001\right)$ and brand passion $\left(\gamma_{22}=0.845, p<0.001\right)$. Additionally, brand trust $\left(\beta_{41}=0.223, p<0.001\right)$ and brand passion $\left(\beta_{42}=0.200, p<0.001\right)$ significantly positively affected brand purchase intentions. In summary, all hypotheses other than $\mathrm{H}_{2}$ were supported (Fig. 2).

The $R^{2}$ values of brand trust, brand passion, and brand purchase intentions were $0.726,0.550$, and 0.569 , respectively. Overall, our research model explained the data well.

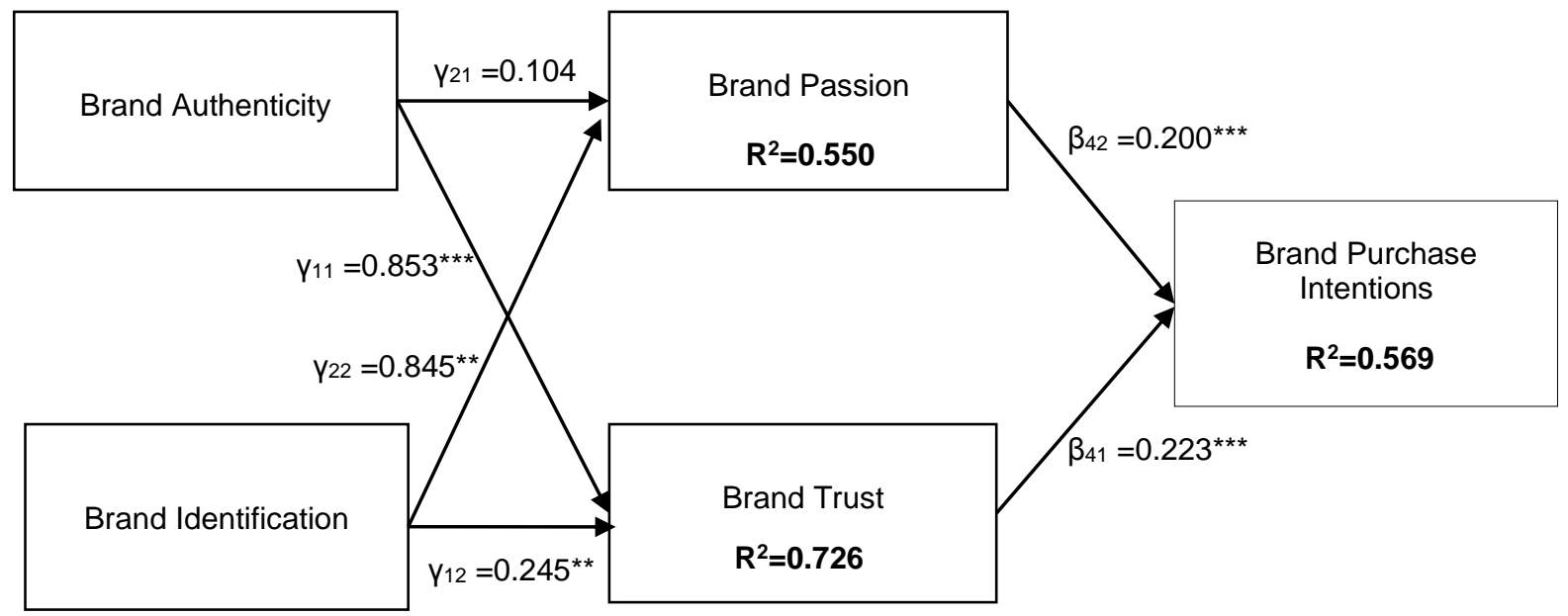

Figure 2: Results of the structural analysis

Note: $x^{2}=1224.066, \mathrm{df}=418, x^{2} / \mathrm{df}=2.928, \mathrm{GFI}=0.852, \mathrm{AGFI}=0.824, \mathrm{RMSR}=0.039, \mathrm{RMSEA}=0.063$ ${ }^{* *}: p<0.01 ;{ }^{* \star *}: p<0.001$ 


\subsection{Post analysis: Mediating Effect and Gender Comparisons}

We further explored the mediation effects of brand trust and brand passion. A Sobel test [8] was performed, and the bootstrapping method suggested by Preacher and Hayes [66] was employed.

According to the regression analysis results (Table 6), brand trust and brand passion both had mediating effects. The Sobel test identified the statistical values for self-identification and social identification to be significantly greater than 1.96. The bootstrapping results (Table 7) revealed that 5000 samplings yielded an accurate outcome. At a 95\% confidence level, neither the confidence interval nor bias confidence interval included zero in the indirect effect of the overall model. Therefore, the indirect effect was significant [82]. Self-identification and social identification were thus mediation variables between exogenous variables and resulting variables.

Table 6: Bootstrapping analysis for the mediating effects of brand trust and brand passion

\begin{tabular}{|c|c|c|c|c|c|c|c|c|c|}
\hline \multirow{3}{*}{ IV } & \multirow{3}{*}{$M$} & \multirow{3}{*}{ DV } & \multirow{3}{*}{$\begin{array}{l}\text { Indirect } \\
\text { effect }\end{array}$} & \multirow{3}{*}{ Mean } & \multirow{3}{*}{ S.E. } & \multicolumn{4}{|c|}{ Bootstrapping 95\% Cl } \\
\hline & & & & & & \multicolumn{2}{|c|}{ Percentile method } & \multicolumn{2}{|c|}{ Bias-corrected } \\
\hline & & & & & & Lower & Upper & Lower & Upper \\
\hline BA & BT & $\mathrm{BPI}$ & 0.126 & 0.126 & 0.036 & 0.056 & 0.195 & 0.057 & 0.196 \\
\hline $\mathrm{BI}$ & BT & $\mathrm{BPI}$ & 0.152 & 0.152 & 0.032 & 0.091 & 0.217 & 0.092 & 0.217 \\
\hline $\mathrm{BI}$ & $\mathrm{BP}$ & $\mathrm{BPI}$ & 0.136 & 0.136 & 0.022 & 0.093 & 0.179 & 0.094 & 0.180 \\
\hline
\end{tabular}

Note: IV: independent variable; M: mediation variable; DV: dependent variable; BA: brand authenticity; $\mathrm{BI}=$ brand identification; $\mathrm{BT}=$ brand trust; $\mathrm{BP}=$ brand passion; $\mathrm{BPI}=$ brand purchase intentions

Table 7: Mediating effects of brand trust and brand passion

\begin{tabular}{|c|c|c|c|c|c|c|c|c|}
\hline IV & $M$ & DV & $\mathrm{IV} \rightarrow \mathrm{DV}$ & $\mathrm{IV} \rightarrow \mathrm{M}$ & $\mathrm{IV}+\mathrm{M} \rightarrow \mathrm{D}$ & & Sobel T€ & \\
\hline & & & & & IV & M & $\begin{array}{l}\text { Statistic } \\
(\mathrm{Z})\end{array}$ & $p$-value \\
\hline $\mathrm{BA}$ & BT & $\mathrm{BPI}$ & $0.469^{* * *}$ & $0.572^{\star * \star}$ & $0.343^{\star \star *}$ & $0.220^{* * *}$ & 3.609 & 0.000 \\
\hline $\mathrm{BI}$ & BT & $\mathrm{BPI}$ & $0.427^{\star \star \star}$ & $0.514^{\star \star \star}$ & $0.274^{\star \star \star}$ & $0.296^{\star \star \star}$ & 4.568 & 0.000 \\
\hline $\mathrm{Bl}$ & BP & $\mathrm{BPI}$ & $0.427^{\star \star \star}$ & $0.784^{\star \star \star}$ & $0.290^{\star \star \star}$ & $0.174^{\star \star \star}$ & 5.519 & 0.000 \\
\hline
\end{tabular}

Note: IV: independent variable; M: mediation variable; DV: dependent variable; BA: brand authenticity; $\mathrm{BI}=$ brand identification; $\mathrm{BT}=$ brand trust; $\mathrm{BP}=$ brand passion; $\mathrm{BPI}=$ brand purchase intentions; ${ }^{* \star *} p<0.001$

Regarding consumer behaviors, women are generally expected to be more emotional than men. Therefore, this study investigated whether men and women exhibit differences in brand passion. The independent sample $t$ test revealed that the $F$ test for brand passion yielded a significant result $(p=0.491>0.05)$. The variances of the two groups exhibited no significant difference. The calculated $t$ statistic was 2.821 with two-tailed significance of $p>0.05$. Thus, the null hypothesis could not be refuted. Unexpectedly, men exhibited significantly higher brand passion toward beauty and cosmetic products than did women (Table 8).

Table 8: Independent samples test

\begin{tabular}{|c|c|c|c|c|c|c|}
\hline \multirow{2}{*}{ Constructs } & Gender & Males & Females & \multirow{2}{*}{$\begin{array}{l}\text { Levene's test for } \\
\text { equality of } \\
\text { variances }\end{array}$} & \multirow{2}{*}{$\mathrm{T}$ value } & \multirow{2}{*}{ Sig. (2-tailed) } \\
\hline & $\mathrm{N}$ & 103 & 381 & & & \\
\hline \multirow{2}{*}{$\begin{array}{l}\text { Brand } \\
\text { passion }\end{array}$} & Mean & 5.214 & 4.899 & \multirow[b]{2}{*}{0.476} & \multirow[b]{2}{*}{2.821} & \multirow[b]{2}{*}{0.005} \\
\hline & $\begin{array}{l}\text { Std. } \\
\text { deviation }\end{array}$ & 0.942 & 1.018 & & & \\
\hline
\end{tabular}

\section{Discussion}

In this study, we constructed a brand model by extending brand authenticity and brand identification to discern how various factors affected the brand purchase intentions of Facebook members who used the fan page of three popular cosmetic brands. According to the results, brand authenticity and brand identification affected brand purchase intention through brand trust and brand passion. Therefore, we identified four crucial paths: brand authenticity $\rightarrow$ brand trust $\rightarrow$ brand purchase intention; brand authenticity $\rightarrow$ brand passion $\rightarrow$ brand purchase intention; brand identification $\rightarrow$ brand passion $\rightarrow$ brand purchase intention; and, brand identification $\rightarrow$ brand trust $\rightarrow$ brand purchase intention. A customer-brand relationship based on these four paths can be a successful long-term relationship. Moreover, this study revealed that brand trust and brand passion both had mediating effects. In addition, men exhibited greater brand passion toward beauty and cosmetic products than did women. 


\subsection{Research Implications}

Brand authenticity was discovered to significantly and positively affect brand trust. This result agreed with those of previous studies [22], [62], [71]. However, brand authenticity did not significantly affect brand passion. According to the results, even if a brand was genuine, natural, honest, consistent, and unique, the brand could not necessarily arouse consumer passion about the brand.

Brand identification significantly and positively affected brand trust [63] and brand passion [3], as previously demonstrated. If a person believes a brand can help them present their personal style, the person trusts the brand. Therefore, enterprises should communicate with consumers to induce them to identify with brands [47]. Many famous brands have successfully formed fan communities using various methods to attract fans (e.g., having film competitions (Doritos) or sharing Internet user stories (Dunkin' Donuts)).

This study determined that brand trust and brand passion significantly and positively affect brand purchase intention, again in agreement with previous studies [1], [74]. Thus, people who trust and love a brand are highly willing to purchase the brand's products. Therefore, brand trust, and brand passion are critical factors that motivate brand fans to demonstrate strong support for a brand.

\subsection{Managerial implications}

Brand authenticity was discovered not to immediately arouse brand passion. This may have been because in the cosmetics industry, some product access channels are cosmetics stores that rely on outdoor advertising and multichannel marketing instead of media or Internet marketing; in addition, professional consultation services are often provided to consumers in cosmetic stores. Although some articles about brand products had been posted on the fan pages of the brands considered in this study and other activities had been undertaken to interact with fans or motivate fans to share on social networks, no active marketing strategies highlighting brand image and spirit had been developed, and the positioning of the brands was ambiguous. Accordingly, fans did not have a close connection with the brands, thereby decreasing their brand passion. Nevertheless, brand authenticity aroused brand trust, which enhanced brand purchase intention. Therefore, brand authenticity is crucial to brand management [71]. In the current consumer market, brand authenticity substantially affects consumer behavior and is the basis of brand trust. Therefore, business operators must be clear about their brand's values, be loyal to the brand's spirit, and honestly fulfill their brand commitments if they are to establish a genuine, natural, and honest brand image and demonstrate brand discriminability and long-term brand consistency.

Loofah water, produced by Kuang Yuan Liang, can be used as an example. This brand is a Taiwanese cosmetics brand that incorporates Taiwanese culture and possesses local characteristics; the product development and brand concept reflect the Taiwanese spirit. In addition, the product is inexpensive and made from local materials, and its advertisements prominently feature Loofah farmers [55]. The brand's management focused on brand spirit; therefore, the product was successfully accepted by consumers and won consumer trust. Bruhn et al. [15] reported that business operators should develop an integrated brand image and enhance brand authenticity. For example, businesses can use media platforms to continually present brand names, logos, and slogans and increase brand credibility. Articles posted on fan pages can thus be used to convey a unique brand spirit (including the original intention of the brand founder and their brand commitments), enhance fans' understanding of the brand's authenticity, increase fans' brand trust, and help fans form brand purchase intentions.

If a brand can reflect consumers' personalities and ideal selves and enhance social status, then the brand can help the consumers reinforce their self-identification. Additionally, brand trust and brand passion strengthen brand purchase intention, which can in turn help consumers develop emotional attachments and convince them to purchase the brand's products. Consumers can use their favorite brands to express their real self or reflect their ideal self. Therefore, business operators should strive to evoke sympathetic responses to brand characteristics and values to create a close connection between a brand and its consumers.

To enhance brand relationships, business operators can invite brand users to post product photos or videos to the brand or product fan pages, write articles to introduce products, and indicate that they are brand fans. Facebook friends and brand fans can click on the like icon if they like a product photo, video, or article, and brand users whose post obtains the most likes could be rewarded. In this manner, product exposure can be increased and brand passion can be aroused, ultimately leading to brand purchase.

Skin care for men is a contemporary societal phenomenon. As the market of women's skin care products becomes saturated, an effective understanding of men's demand for specific skin care products generates a level of brand passion among men that far exceeds that among women. For example, Lancôme has established itself as a brand that focuses on developing professional skin care products for older men; $37 \%$ of its customers are over the age of 40. Biotherm, another skin care company, noted an increasing proportion of men actively seeking skin care and aging prevention, and that men demonstrate greater loyalty in skin care product selection. This indicates that that men's brand passion toward beauty and skin care products has slowly overtaken that of women. 
The Internet is powerful and penetrative; fan pages are an excellent tool for marketing brands and strengthening consumer-brand relationships [46]. Business operators should endeavor to create an atmosphere on a fan page in which brand fans actively interact with one another; if they succeed, consumers will establish brand trust [31] and emotional attachment [58]. Fan pages are thus crucial channels for business operators to strengthen the consumerbrand relationship.

From a management perspective, online community managers should concentrate on brand characteristics and identification. A unique brand spirit and characteristic can affect brand trust, and brand identification is crucial for strengthening the relationship between community members and brand manufacturers. Community managers must understand how to maintain these relationships. Brand trust and brand passion played a critical role in our research model, but these qualities cannot be formed overnight. Therefore, how brand manufacturers can strengthen the relationship between community members and their brands is an urgent issue.

\subsection{Limitations and Future Directions}

In this study, we endeavored to meet all the requirements of management science research; however, this study did have some limitations. The limitations and corresponding suggestions are as follows.

First, the present study conducted a cross-sectional survey; future studies could adopt a longitudinal method to observe how community members make purchase decisions about their favorite brands, understand the causal relationships between various variables, and develop an effective assessment tool for subsequent analysis and verification. Second, a nonrandom sampling method was used in this study, and the participants were required to complete a questionnaire regarding their favorite brands. In future research, other types of social groups (e.g., discussion forums) could be investigated. Third, the research targets in this study were cosmetics brand fans, and most participants were women; therefore, results may have been biased. We suggest that in future studies, equal numbers of men and women should be recruited.

Finally, in our research framework, some psychological factors were not considered. Brand romance is one such factor and describes the passion about a brand and the close relationship formed with it when a person is in love with a brand [64]. Another psychological factor is the cocreation experience [13], which is the sharing of purchase experiences among community members that can affect online community members' purchase intentions. If these factors are considered, brand loyalty may be reinforced, and brand fans may become enthusiasts who will defend and recommend the brand. Consequently, the resulting economic benefits will likely exceed those gained from more traditional advertising.

\section{References}

[1] N. Albert and D. Merunka, The role of brand love in consumer-brand relationships, Journal of Consumer Marketing, vol. 30, no. 3, pp. 258-266, 2013

[2] N. Albert, D. Merunka and P. Valette-Florence, Brand love: Antecedents and consequences, in Proceedings of the Consumer Brand Relationship Colloquium, Florida, FL, 2010, pp. 17-19.

[3] N. Albert, D. Merunka and P. Valette-Florence, Brand passion: Antecedents and consequences, Journal of Business Research, vol. 66, no. 7, pp. 904-909, 2013.

[4] S. S. Andaleep and S. F. Anwar, Factors influencing customer trust in salespersons in a developing country, Journal of International Marketing, vol. 4, no. 4, pp. 35-52, 1996.

[5] J. C. Anderson and D. W. Gerbing, Structural equation modeling in practice: A review and recommended twostep approach, Psychological Bulletin, vol. 103, no. 3, pp. 411-423, 1988.

[6] R. P. Bagozzi and Y. Yi, On the evaluation of structural equation models, Journal of the Academy of Marketing Science, vol. 16, no. 1, pp. 74-94, 1988.

[7] R. Ballantyne, A. Warren and K. Nobbs, The evolution of brand choice, The Journal of Brand Management, vol. 13, no. 4, pp. 339-352, 2006.

[8] M. E. Sobel, Asymptotic intervals for indirect effects in structural equations models, in Sociological Methodology, (S. Leinhart, Ed.). San Francisco: Jossey-Bass, 1982, pp.290-312.

[9] H. H. Bauer, D. Heinrich and I. Martin, How to create high emotional consumer-brand relationships? The causalities of brand passion, in Proceedings of the Australian \& New Zealand Marketing Academy Conference, University of Otago, Australia, 2007, pp. 2189-2198.

[10] E. P. Becerra and V. Badrinarayanan, The influence of brand trust and brand identification on brand evangelism, Journal of Product \& Brand Management, vol. 22, no. 5-6, pp. 317-383, 2013.

[11] E. P. Becerra and P. K. Korgaonkar, Effects of trust beliefs on consumers' online intentions, European Journal of Marketing, vol. 45, no. 6, pp. 936-962, 2011.

[12] C. B. Bhattacharya and S. Sen, Consumer-company identification: A framework for understanding consumers' relationships with companies, Journal of Marketing, vol. 67, no. 2, pp. 76-88, 2003.

[13] L. Blasco-Arcas, B. Hernandez-Ortega and J. Jimenez-Martinez, The online purchase as a context for cocreating experiences: Drivers of and consequences for customer behavior, Internet Research, vol. 24, no. 3, pp. 393-412, 2014. 
[14] M. Bruhn, S. Schnebelen and D. Schäfer, Antecedents and consequences of the quality of e-customer-tocustomer interactions in B2B brand communities, Industrial Marketing Management, vol. 43, no. 1, pp. 164-176, 2014.

[15] M. Bruhn, V. Schoenmüller, D. Schäfer and D. Heinrich, Brand authenticity: Towards a deeper understanding of its conceptualization and measurement, Advances in Consumer Research, vol. 40, pp. 567-576, 2012.

[16] G. Cappannelli and S. C. Cappannelli, Authenticity: Simple Strategies for Greater Meaning and Purpose at Work and at Home. Cincinnati, OH: Emmis Books, Ohio, 2004.

[17] A. Chakravarty, Y. Liu and T. Mazumdar, The differential effects of online word-of-mouth and critics' reviews on pre-release movie evaluation, Journal of Interactive Marketing, vol. 24, no. 3, pp. 185-197, 2010

[18] A. Chaudhuri and M. B. Holbrook, The chain of effects from brand trust and brand affect to brand performance: The role of brand loyalty, Journal of Marketing, vol. 65, no. 2, pp. 81-93, 2001.

[19] W. W. Chin, The partial least squares approach to structural equation modeling, in Modern Methods for Business Research, (G. A. Marcoulides, Ed.). Mahwah: Lawrence Erlbaum, 1998, pp. 295-358.

[20] H. Choi, E. Ko, E. Y. Kim, and P. Mattila, The role of fashion brand authenticity in product management: A holistic marketing approach, Journal of Product Innovation Management, vol. 32, no. 2, pp. 233-242, 2014

[21] S. C. Chu and Y. Kim, Determinants of consumer engagement in electronic word-of-mouth (eWOM) in social networking sites, International Journal of Advertising, vol. 30, no. 1, pp. 47-75, 2011

[22] S. P. Coary, Scale construction and effects of brand authenticity, Ph.D. dissertation, Southern California University, CA: Los Angeles, 2013.

[23] Cosmetic Marketing Research Intuition. (2016, March) UrCosme research analysis for the fourth quarter in 2015. CMRI. [Online]. Available: https://cmri.itrue.com.tw/

[24] E. Delgado-Ballester, J. L. Munuera-Aleman and M. J. Yague-Guillen, Development and validation of a brand trust scale, International Journal of Market Research, vol. 45, no. 1, pp. 35-54, 2003

[25] D. T. Donavan, S. Janda and J. Suh, Environmental influences in corporate brand identification and outcomes, Journal of Brand Management, vol. 14, no. 1-2, pp. 125-136, 2006.

[26] Edelman Public Relations, Edelman Trust Barometer. New York, NY: Edelman Public Relations, 2013.

[27] F. Eggers, M. O'Dwyer, S. Kraus, C. Vallaster, and S. Gueldenberg, The impact of brand authenticity on brand trust and SME growth: A CEO perspective, Journal of World Business, vol. 48, no. 3, pp. 340-348, 2013.

[28] R. Elliott and N. Yannopoulou, The nature of trust in brands: A psychosocial model, European Journal of Marketing, vol. 41, no. 9-10, pp. 988-998, 2007.

[29] J. E. Escalas and J. R. Bettman, You are what they eat: The influence of reference groups on consumers' connections to brands, Journal of Consumer Psychology, vol. 13, no. 3, pp. 339-348, 2003.

[30] J. E. Escalas and J. R. Bettman, Self-construal, reference groups, and brand meaning, Journal of Consumer Research, vol. 32, no. 3, pp. 378-389, 2005.

[31] C. Flavián and M. Guinalíu, Consumer trust, perceived security and privacy policy: Three basic elements of loyalty to a web site, Industrial Management \& Data Systems, vol. 106, no. 5, pp. 601-620, 2006

[32] C. Fornell and D. F. Larcker, Evaluating structural equation models with unobservable variables and measurement error, Journal of Marketing Research, vol. 18, no. 1, pp. 39-50, 1981.

[33] J. F. Gaski and J. R. Nevin, The differential effects of exercised and unexercised power sources in a marketing channel, Journal of Marketing Research, vol. 22, no. 2, pp. 130-142, 1985.

[34] D. Gefen, D. W. Straub and M. C. Boudreau, Structural equation modeling and regression: Guidelines for research practice, Communications of AIS 2000, vol. 4, no. 7, pp. 1-80, 2000.

[35] J. H. Gilmore and B. J. II Pine, Authenticity-What Consumers Really Want. Boston, MA: Harvard Business School Press, 2007

[36] H. Y. Ha and H. Perks, Effects of consumer perceptions of brand experience on the web: Brand familiarity, satisfaction and brand trust, Journal of Consumer Behaviour, vol. 4, no. 6, pp. 438-452, 2005.

[37] M. R. Habibi, M. Laroche and M. O. Richard, The roles of brand community and community engagement in building brand trust on social media, Computers in Human Behavior, vol. 37, pp. 152-161, 2014.

[38] J. F. Jr. Hair, W. C. Black, B. J. Babin, and R. E. Anderson, Multivariate Data Analysis (7th ed.). Upper Saddle River, NJ: Pearson Prentice-Hall, 2010.

[39] S. A. Haslam, Psychology in Organizations: The Social Identity Approach (2nd ed.). London, UK: Sage Publications, 2004.

[40] H. He, Y. Li and L. Harris, Social identity perspective on brand loyalty, Journal of Business Research, vol. 65, no. 5 , pp. 648-657, 2012

[41] J. Henseler, C. M. Ringle and M. Sarstedt, A new criterion for assessing discriminant validity in variance-based structural equation modeling, Journal of the Academy Marketing Science, vol. 43, no. 1, pp. 115-135, 2015.

[42] H. Jiménez-Martínez and M. De Hoyos, Structure, dimensionality and consciousness of the state of flow in social commerce, in Proceedings of the 28th Congreso de Marketing AEMARK, España, 2016, pp. 685-699.

[43] M. K. Hogg, A. J. Cox and K. Keeling, The impact of self-monitoring on image congruence and product/brand evaluation, European Journal of Marketing, vol. 34, no. 5-6, pp. 641-667, 2000.

[44] L. Hu and P. M. Bentler, Cutoff criteria for fit indexes in covariance, Structural Equation Modeling, vol. 6, no. 1, pp. 1-55, 1999

[45] J. Hwang and J. Kandampully, The role of emotional aspects in younger consumer-brand relationships, Journal of Product \& Brand Management vol. 21, no. 2, pp. 98-108, 2012.

[46] B. Jahn and W. Kunz, How to transform consumers into fans of your brand, Journal of Service Management, vol. 23, no. 3, pp. 344-361, 2012. 
[47] R. Jones and Y. K. Kim, Single-brand retailers: Building brand loyalty in the off-line environment, Journal of Retailing and Consumer Services, vol. 18, no. 4, pp. 333-340, 2011.

[48] C. K. Kim, H. Dongchul and P. Seung-Bae, The effect of brand personality and brand identification on brand loyalty: Applying the theory of social identification, Japanese Journal of Psychological Research, vol. 43, no. 4, pp. 195-206, 2001.

[49] K. Kim, J. Park and J. Kim, Consumer-brand relationship quality: When and how it helps brand extensions, Journal of Business Research, vol. 67, no. 4, pp. 591-597, 2014.

[50] N. Kim, J. Lee, H. Kwon, M. Jeon, S. Lee and S. Kim, 2012 Trend Korea. Mi Raeeuichang, Korea: Seoul, 2011.

[51] S. Kuenzel and S. V. Halliday, Investigating antecedents and consequences of brand identification, Journal of Product and Brand Management, vol. 17, no. 5, pp. 293-304, 2008.

[52] S. Kuenzel and S. V. Halliday, The chain of effects from reputation and brand personality congruence to brand loyalty: The role of brand identification, Journal of Targeting, Measurement and Analysis for Marketing, vol. 18, no. 3/4, 167-176, 2010.

[53] M. Laroche, M. R. Habibi and M. O. Richard, To be or not to be in social media: How brand loyalty is affected by social media? International Journal of Information Management, vol. 33, no. 1, pp. 76-82, 2013.

[54] M. M Long and L. G. Schiffman, Consumption values and relationships: Segmenting the market for frequency programs, Journal of Consumer Marketing, vol. 17, no. 3, pp. 214-232, 2000.

[55] L. C. Lu, W. P. Chang and H. H. Chang, Consumer attitudes toward blogger's sponsored recommendations and purchase intention: The effect of sponsorship type, product type, and brand awareness, Computers in Human Behavior, vol. 34, pp. 258-266, 2014

[56] N. Luo, M. Zhang and M. H. Y. Wang, How community interactions contribute to harmonious community relationships and customers' identification in online brand community, International Journal of Information Management, vol. 36, no. 5, pp. 673-685, 2016

[57] P. Martínez and I. Rodríguez del Bosque, CSR and customer loyalty: The roles of trust, customer identification with the company and satisfaction, International Journal of Hospitality Management, vol. 35, no. 1, pp. 89-99, 2013.

[58] A. S. Mattila and J. Wirtz, The impact of knowledge types on the consumer search process: An investigation in the context of credence services, International Journal of Service Industry Management, vol. 13, no. 3, pp. 214230, 2002.

[59] J. H. McAlexander, J. W. Schouten and H. F. Koenig, Building brand community, Journal of Marketing, vol. 66, no. 1, pp. 38-54, 2002

[60] M. Mohammadian and Y. Karimpour, Identifying the factors influencing the feeling of love toward a brand: The adidas case, National Park-Forschung in der Schweiz (Switzerland Research Park Journal), vol. 103, no. 1, pp. 94-122, 2014

[61] A. M. Jr. Muñiz and T. C. O'Guinn, Brand communit,. Journal of Consumer Research, vol. 27, no. 4, pp. 412432,2001

[62] J. Napoli, S. J. Dickinson, M. B. Beverland and F. Farrelly, Measuring consumer-based brand authenticity, Journal of Business Research, vol. 67, no. 6, pp. 1090-1098, 2014.

[63] S. B. Park and N. N. Chung, Mediating roles of self-presentation desire in online game community commitment and trust behavior of massive multiplayer online role-playing games, Computers in Human Behaviors, vol. 27, no. 6, pp. 2372-2379, 2011

[64] H. Patwardhan and S. K. Balasubramanian, Brand romance: A complementary approach to explain emotional attachment toward brands, Journal of Product \& Brand Management, vol. 20, no. 4, pp. 297-308, 2011.

[65] P. M. Podsakoff, S. B. MacKenzie, J. Y. Lee, and N. P. Podsakoff. Common method biases in behavioral research: A critical review of the literature and recommended remedies, Journal of Applied Psychology, vol. 88, no. $5,879-903,2003$.

[66] K. J. Preacher and A. F. Hayes, Asymptotic and resampling strategies for assessing and comparing indirect effects in multiple mediator models, Behavior Research Methods, vol. 40, no. 3, pp. 879-891, 2008

[67] F. Reichheld, The one number you need to grow, Harvard Business Review, vol. 81, no. 12, pp. 46-55, 2003.

[68] H. D. Rozanski, A. G. Baum and B. T. Wolfsen, Brand zealots: Realizing the full value of emotional loyalty, Strategy \& Business, vol. 17, no. 4, pp. 51-62, 1999.

[69] A. Şahin, C. Zehir and H. Kitapçı, The effects of brand experiences, trust and satisfaction on building brand loyalty: An empirical research on global brands, Procedia-Social and Behavioral Sciences, vol. 24, no. 1, pp. 1288-1301, 2011.

[70] D. Scarpi, Does size matter? An examination of small and large web-based brand communities, Journal of Interactive Marketing, vol. 24, no. 1, pp. 14-21, 2010.

[71] M. Schallehn, C. Burmann and N. Riley, Brand authenticity: Model development and empirical testing, Journal of Product \& Brand Management, vol. 23, no. 3, pp. 192-199, 2014.

[72] R. J. Sternberg, A triangular theory of love, Psychological Review, vol. 93, no. 2, pp. 119-135, 1986

[73] R. J. Sternberg, Construct validation of a triangular love scale, European Journal of Social Psychology, vol. 27, no. 3, pp. 313-335, 1997

[74] K. R. Swimberghe, M. Astakhova and B. R. Wooldridge, A new dualistic approach to brand passion: Harmonious and obsessive, Journal of Business Research, vol. 67, no. 12, pp. 2657-2665, 2014.

[75] H. Tajfel and J. C. Turner, The social identity theory of intergroup behavior, in Psychology of Intergroup Relations (2nd ed.), (S. Worchel and W. G. Austin, Eds.). Chicago: Nelson-Hall, 1985, pp. 7-24.

[76] A. M. Turri, K. H. Smith and E. Kemp, Developing affective brand commitment through social media, Journal of Electronic Commerce Research, vol. 14, no. 3, pp. 201-214, 2013. 
[77] J. C. Turner, M. A. Hogg, P. J. Oakes, S. D. Reicher, and Wetherell, M. S., Rediscovering the social group: A self-categorization theory, American Journal of Sociology, vol. 94, no. 6, pp. 1514-1516, 1987.

[78] U. Tuškej, U. Golob and K. Podnar, The role of consumer-brand identification in building brand relationship, Journal of Business Research, vol. 66, no. 1, pp. 53-59, 2013.

[79] G. Wang, Attitudinal correlates of brand commitment: an empirical study, Journal of Relationship Marketing, vol. 1, no. 2, pp. 57-75, 2002

[80] C. H. Yeh, Y. S. Wang and K. Yieh, Predicting smartphone brand loyalty: Consumer value and consumer-brand identification perspective, International Journal of Information Management, vol. 36, no. 3, pp. 245-257, 2016.

[81] Y. H. Yeh and S. M. Choi, MINI-lovers, maxi-mouths: An investigation of antecedents to eWOM intention among brand community members, Journal of Marketing Communications, vol. 17, no. 3, pp. 145-162, 2011.

[82] L. Zhao, Y. Lu, B. Wang, P. Y. K. Chau and L. Zhang, Cultivating the sense of belonging and motivating user participation in virtual communities: A social capital perspective, International Journal of Information Management, vol. 32, no. 6, pp. 574-588, 2012. 


\section{Appendix 1: Scale items}

\section{Construct/Items}

Brand Authenticity [15]

1. I think this brand is consistent over time.

2. I think the brand stays true to itself.

3. Brand offers continuity.

4. The brand has a clear concept that it pursues.

5. The brand is different from all other brands.

6. Brand stands out from other brands.

7. I think the brand is unique.

8. The brand clearly distinguishes itself from other brands.

9. My experience of the brand has shown me that it keeps its promises.

10. The brand delivers what it promises.

11. Brand's promises are credible.

12. The brand makes reliable promises.

13. The brand does not seem artificial.

14. The brand makes a genuine impression.

15. The brand gives the impression of being natural.

Brand Identification [81]

1. The brand says a lot about the kind of person I am.

2. The brand's image and my self-image are similar in many respects.

3. The brand plays an important role in my life.

Brand Trust [37]

1. This is an honest brand.

2. I trust this brand.

3. This brand is safe.

Brand Passion [49]

1. No other brand in the category can quite take the place of this brand.

2. I have a powerful attraction toward this brand.

3. I have feelings for this brand that I don't for many other brands. 
Brand Purchase Intentions [10]

1. In the near future, I would probably buy the brand.

2. In the near future, I intend to buy beauty product made by the brand.

3. In the near future, I would likely buy the brand.

4. In the near future, I would possibly buy the brand. 